\title{
ANALYZING STUDENTS' DIFFICULTIES TOWARD LISTENING COMPREHENSION
}

\author{
Darti \\ Universitas Islam Negeri Alauddin Makassar \\ dartijagsya@gmail.com \\ Andi Asmawati \\ Universitas Islam Negeri Alauddin Makassar \\ asma_wh@yahoo.com
}

\begin{abstract}
The aim of the study was to found out the problems encountered the students in listening comprehension. Descriptive method was used to analyze and to find the solution about the problems. The research was conducted in State Islamic University of Alauddin Makassar. The population of this study was second semester students of English Education Department of Tarbiyah and Teacher training Faculty Academic year 2016/2017. There were 37 students as the subject in this study. Data were gathered by questionnaire and interview while observation during listening was used to confirm students' answer. The result of analyzing students' difficulties toward listening comprehension showed that listening is very difficult skill for students who study foreign language. It was based on three factors influencing their listening; they were listening material, listener factor, and physical setting. Therefore, accents, pronunciation, speed of speech, insufficient vocabulary, different accent of the speakers, lack of concentration, and bad quality of recording were the major problems encountered by students' English Education Department. Understanding students' difficulties enable the lecturer to help the students developing the effective learning strategies and ultimately improve their listening. Solutions to overcome the problems were: the teacher should adapt and improve listening material, activate students' vocabulary, give the students variety of accent while practice listening in language laboratory, improve their pronunciation by training from native speakers, building students' knowledge about the topic, give some strategy in listening, and always motivate students. The solutions were made as a suggestion for the lecturers.
\end{abstract}

Keywords: Students’ Difficulties, Listening Problems, Listening Comprehension

\section{A. BACKGROUND}

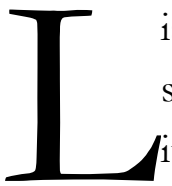

istening is an essential part of English as a foreign language. It seems like the other skills such as writing, reading, and speaking. Listening is very important skill because it is the most widely used in daily life. Learning listening will help us to improve speaking skill considerably. People need to hear various types of English repeatedly and continuously if they want to communicate properly, meaningful, and naturally. It means that without hearing people cannot acquire language because listening provides language input. As Rost in Hien (2015) stated listening as foreign language learning is paramount important since it provides the language input. As an input skill, listening plays a crucial role in students' language development.

Teaching listening needs more attention in order to develop students' language. In some cases of the language classroom, listening was considered to be the most difficult language skill for students because it needs more attention and concentration to comprehend the 
material that included understanding dialogue and monologue text. It could be said that listening is a complex process in which many things happen simultaneously inside the mind. Nevertheless, the lecturers hold a very crucial demand in learning process. The lecturer had ability to handle the students and the class circumstances. When the students find difficulties in their listening, it was naturally because they were studying. It became the lecturers' responsible to solve the difficulties faced by the students. However, most lecturers did not pay attention about that. The teacher might assume that it was not important to do.

According to some previous research from Hamouda (2013), Abidin (2013), Anadapong (2011) who completed the related study, they concluded that in order to help students to improve their listening ability, language lecturer had to understand students' listening difficulties in comprehending listening text, and instruct effective listening strategies to help the students to solve their listening difficulties. As well as the lecturer knows their students' difficulties, students as subject have important role in developing their listening. Students successful in listening depend on how they can know and solve their difficulties. If the students know the problems influence their listening, it would be easy to find the solution. They will study hard in order to improve their listening. Furthermore, Nurpahmi (2015) found that activating students' prior knowledge can improve students' listening skill.

In addition, analyzing students' difficulties toward listening comprehension helped the students in listening test as well as TOEFL test. Many language learners found difficulties in listening TOEFL especially the students who completed their degree. For example, the students in English Education Department of State Islamic University of Alauddin Makassar, they were required TOEFL test which includes listening comprehension before getting their degree. Meanwhile, they encountered many problems in doing their listening comprehension of the test.

There were some difficulties faced by the student such as the lack of vocabulary, understanding structure, unable to comprehend natural spoken, lose confidence, maintaining concentration, bad recording. As Hamouda (2013) stated that factors causing students listening comprehension problem are categorized into different sources including problems related to the listening text, listening problems related to task and activities, listeners problems related to the listener and teacher's methodology. Thus, it was the way to find out the students' difficulties from three main areas: listener factors, listening material and physical setting. Also, it became guidance for the teacher to overcome listening comprehension. Hence, coming up a study entitled: Analyzing Students' Difficulties toward Listening 
Volume 3, Number 02, December 2017

Comprehension of English Education Department of Tarbiyah and Teaching Faculty at UIN Alauddin Makassar.

\section{B. REVIEW OF RELATED LITERATURE}

Hamouda (2013) found in his research entitled An Investigation of Listening Comprehension Problems Encountered by Saudi Students in the EL Listening Classroom. This research use quantitative and qualitative methods of data collection. This study was carried out with the participation of 60 first-year student majoring in English language and translation at Qassim University. Their ages range from 20 to 22 years old. Listening comprehension seems to be the weakest skill and students encounter various kinds of listening problems. Data was gathered by means of questionnaires and interview. The research found that accent, pronunciation, speech of speech, insufficient vocabulary, different accent of speaker, lack of concentration, anxiety, and bad quality of recording were the major listening comprehension problems encountered by EFL Saudi learners.

Abidin (2013) in his research entitled English Listening Comprehension Problems of Students from China Learning English in Malaysia. The research used a qualitative method to collect data from three Chinese students taking English Listening Comprehension (ELC) in University Science Malaysian (USM). This study is a research report related to the problems encountered by China's students in ELC learning. The interview was conducted to investigate students' perspective through the main question concerning the problems of the Chinese students in their ELC self-learning process, in three steps, which include the pre-listening, while listening and post-listening. Findings from this study indicate that the main problem faced by the Chinese students is the lack of prior knowledge in English vocabulary, and this inhibits their understanding in the listening process. Moreover, the differences in the accent of the native speakers prohibit the proper understanding of the listening content, the short span of concentration, and the learning habits of Chinese students were discussed as the problems of the ELC learning.

Anadapong (2011) mentioned in his research entitled A Study of English Listening Problems and Listening Proficiency of Business at Bangkok University. This study was conducted with thirty of Business student at Bangkok University with the aim investigating their English listening problem and listening proficiency. Questionnaire, IELTS test, and Interview were used in this study us tools to collect data. As a result, the data was analyzed by using SPSS. The result of the study revealed that students that main reason caused listening problem for the students is 
the listening text. However, the factors that mostly caused listening problems were lack of practicing listening skill and lack of exposure to different kinds of listening materials.

Yousif (2006) mentioned in his research entitled Listening Comprehension Difficulties as Perceived. The study investigated lecture comprehension problems of first year students listening to lectures in a FL subject matter classroom. Data was collected regarding the lecture comprehension difficulties of these students by means of a short open-ended questionnaire and interview. The subjects of the study were 50 first-year students majoring in English in their second semester at Almajmah College of Education. They were admitted to the English department on the merit of acquiring $80 \%$ or more on the school certificate examination. The analysis of the data provides an index of linguistic, conceptual, discourse, acoustic, environmental and psychological variables that hinder effective comprehension. The results of the study have implications for both EFL teachers and subject matter lecturers in the particular setting in which it was conducted as well as in similar FL tertiary levels. They discussed several obstacles that impact comprehension. These are divided into three main areas: listener factors, speaker factors and text factors.

\section{Listening Comprehension}

Listening as Howat and dakin in Hien (2015) defined the ability to identify and to understand what other are saying. The aim of listening comprehension to comprehend what the people said in English. As Chastain (1971) in Bingol stated the aim of listening comprehension is understand the native conversation at normal rate in a spontaneous condition. This involves understanding a speaker accent and pronunciation, his grammar and his vocabulary and grasping his meaning. Helgesen and Brown (2007) Listeners are actively paying attention and working on understanding and interpreting what they hear. Listening is the process based instruction. It was called as metacognition.

Steinberg (2007) in Bingol mentioned listening process as "the ability of one individual perceiving another via sense, aural organs, assigning a meaning to the message and comprehending it. Listening include some features. The most important features can be defined as: coping with the sounds, understanding intonation and stress, copying with redundancy and noise, predicting, understanding colloquial vocabulary, fatigue, understanding different accents, using visual and enviromental clues. Planning, exercises, listening materials, task and visual materials should be taken into consideration. The teacher should produce a suitable discourse while using recordings. A preset purpose, ongoing learner response, motivation, success, simplicity, and feedback should be the things considered while preparing 


\section{Volume 3, Number 02, December 2017}

the listening comprehension. That is the way listening is a complex process. According to Buck (1978) Listening comprehension is a process, a very complex process, and if they want to measure it, we must first understand how that process works. Thus, listening comprehension is a complex process to identify and to understand dialog and monolog what the speaker said which used audio cassette or watched VCD in English.

2. Listening Problems

Listening difficulties is internal and external characteristic that interrupt text understanding directly related to cognitive. Hamouda (2013) stated that factors causing students listening comprehension problem were categorized into different sources including problems related to the listening text, listening problems related to task and activities, listeners problems related to the listeners and lecture's methodology.

The difficulties that faced by the student would interrupt during the process listening comprehension especially those who learn English as foreign language in non-native setting. According to Lindsay, a major problem students have, in contrast to students studying English is that they have little or no experience in 'real' listening to fall back on, no memory of past learning or social experiences. The facts that they lived in non-English speaking country were major factor to their listening problems.

\section{RESEARCH METHODOLOGY}

Descriptive method was used to analyze and to find the solution about the listening problems. The researcher used observation, questionnaire, and interview to gain data. Observation was used to confirm students' answer about questionnaire. It was distributed to know the students' difficulties. Interview process was held to know deeply about the students' difficulties. Then, all of the result questionnaire and interview were analyzed.

\section{RESULT AND DISCUSSION}

\section{The Analysis of the Data Collected from Questionnaire}

a. Listening Problems Related to the Content of The Listening Text

The materials became the main source of listening comprehension problems. Some problems found of listening material were unfamiliar words, difficult grammatical structure, limited vocabulary, and long spoken text.

1) Problems pertinent to unfamiliar word 
The first question were asked to know unfamiliar word including jargon and idioms, interfered the learners' listening comprehension. There were 22 from 37 student have responded that unfamiliar words including jargon and idioms interfered with their listening comprehension. It means that vocabulary is a big obstacle to most students in listening comprehension. The students did not know what are the different of jargon and idioms. Their practice in listening too limited because they learning listening only in the laboratory when they learn about listening comprehension. It became their problems pertinent to unfamiliar word.

2) Problem pertinent to poor grammar

The second question was asked to know whether complex grammatical structures interfered with the learner's listening comprehension. There are 26 from 37 students have responded that difficult grammatical structures interfered their listening comprehension. The student's answer point out difficult grammatical structures caused much trouble to students. It means that know about the structural component of the text most important in listening comprehension. Some students found difficulties because they poor of grammar so their ability to listen complex sentence too bad. Understand complex sentence spend much time also.

3) Problem pertinent to understand every single word in the text

Based on the respondents' answer about the difficulties to understand every single word in the speech, there were 25 students said yes and only 12 students said no. The students cannot answer the question from the speaker because they try to understand every single word. Actually, it is unnecessary and impossible because when they are trying hard to get every individual word can waste their time to answer and make them loss focus.

4) Problem pertinent length of spoken text

Both vocabulary and the difficulty of grammatical structures, the length of the spoken text was one of main reasons why the student difficult to understand most of the talk. Based on the 37 respondents, there were only 7 students answered No this question. This result clearly shows that the length spoken text can be one major factor interfere the learners' listening comprehension because it distracted their concentration. Long spoken text bore the student also. Therefore, it is possible to infer that long spoken text interfere learners' listening comprehension.

5) Problem pertinent to interpret the meaning of spoken text 


\section{Volume 3, Number 02, December 2017}

Long spoken text was one factor distract concentration of the student during listening comprehension. It is also make the student difficult to interpret what the speaker said. The result of 37 students show that, there were 27 students answer yes and 10 students answer no. Thus, know about interpret the meaning of the spoken text very important in listening comprehension. The students' found difficult to interpret meaning of spoken text because they limited English vocabulary and there were many unfamiliar topic

6) Problem pertinent fatigue when listen long spoken text

Foreign language learners felt fatigue and distracted when they listen a long spoken text because they tried to understand unfamiliar sounds. The results from 25 respondents had answered yes and 12 students answered no. Thus, felt fatigue distract students' attention from interpret the meaning of the text and made them loss concentration. Listening long spoken text make the listener felt tired because they tried to understand the unfamiliar sounds, lexis, and syntax for long stretches of time. The learners' might miss the text also when there was a lapse in concentration.

7) Problem pertinent to unfamiliar topic

From the results of questionnaire, unfamiliar topic is one of students' difficulties in listening comprehension. There were 27 students have responded yes. The students' respond indicated that many students find difficult in listening when the topic is unfamiliar. It means that the student construct their understanding basis on their experience. Sometimes there were dialog and talks about different topic such as economy, so many students do not know any of the words related to economy. The problems may affect them because they lack of read about that. They had to increase their lexical knowledge by reading and listening.

8) Problem pertinent to use reduced form

Reduced forms are an important thing listening comprehension, but all students did not understand about that. It can be known from the result of the questionnaire. From 37 students, there were 28 students answered yes and only 9 answered no. Many students answered yes because they poor about grammar structure. It shows the students need to improve their learning about reduced form in order to make them easy to answer the question in listening comprehension.

9) Problem pertinent long conversation

Long conversation is one of students' difficulties to get meaning in listening comprehension. Even if it hard to understand it, also have difficult grammatical. From the 
respond of the questionnaire shows that only 11 students have responded no in this section. It means that long conversation is students' difficulties in listening comprehension.

10) Problem pertinent basic background knowledge

Background knowledge is an important thing that can influence students' listening comprehension. Even if they have mastered of the skill, lack of background knowledge can cause reduced their listening comprehension. The result of questionnaire shows that from 37 respondents there are 25 students answer yes. They students who answer yes lack of knowledge about that. It shows that background knowledge is very important thing to get meaning of the listening text.

b. Listening Problems Related to the Listener

Students' difficulties in listening not only from the material of the listening but also lack of English language skill from the listeners. Understanding listening also need concentration, when the students feel nervous or anxious they cannot concentration. The problems included in listener factor were fear before doing listening, feel worried, their attention, difficult to recognize signal, lose focus, encountering unknown word, lose concentration, listening without transcript.

1) Problem pertinent to inability of understanding listening

Before doing listening comprehension tasks, there were 23 students have responded they fear that they cannot understand what they will hear. Lack of confidence the students before doing listening comprehension because they have no much knowledge and lack of practice in listening. They were shy with her friends also when they don't understand something. It is the lecturer's job to arouse the students' interest, help them gain confidence and make sure that they can achieve success in listening with the limited amount of English. It means that the lecturer have to find good strategy to make the class enjoyable and relaxing.

2) Problem pertinent to anxiety

Based on the questionnaire, there were 33 students have responded that they feel worried if they don't understand spoken text. The students panic when they fail to understand spoken text because they fear to get lower score in listening. These figures point out this factor creates psychological problems of the learners. The lecturer had to motivate them in order to make them feel relax during listening.

3) Problem pertinent to the unclear pronunciation 


\section{Volume 3, Number 02, December 2017}

All of the students from 37 peoples have responded that they difficult in listening because unclear pronunciation. They recognized the words in written text but they couldn't understand what they hear. It means that unclear pronunciation of some speaker is also considered as a source of listening problem. Many students' said they were not successful since it was impossible for them to know what the speaker said because they lack of pronunciation ability. They need to practice the words with pronunciation clearly.

4) Problem pertinent intonation of the speaker

To know what the speaker said the student must paying attention the intonation of the speaker. But in reality, many students do not paying attention of the speaker. The result from 37 students, there were 3 students paying attention to the speaker. It become a big problem for non native language because intonation very important to comprehension. Many students said that it was not important to understand what the speaker said.

5) Problem pertaining to use signal words

Signal words help the listener to grasp the thread of thought in the material. The listener can predict what may come next by using signal word. The result of the questionnaire shows that the student difficulties to recognize signal word. From 37 students, there were 32 students said it. The students lack of knowledge about the function of signal words. They fail to recognize the signal which indicated that the speaker was moving from one point to another, giving an example, or repeating a point. It means that the lecturer and the students have to pay attention about that.

6) Problem pertinent to lose focus when get an expected answer

From the table, there were 29 students from 37 respondents lose focus when get an expected answer in their mind. This problem will interrupt their listening because they can unable to concentrate and miss their listening. When they understand what the speaker said, they try to looking for the answer. They spend much time to choose the correct answer. Finally, they miss next question.

7) Problems pertinent to the use of unknown words

When encountering an unknown word, many students stop listening and think about the meaning of new word. There were 20 students said yes and 17 students answered no. This problem interrupting their listening and make them miss some information in listening. There were so many unfamiliar words in listening comprehension. When they listening long conversation and talk, they try to understand all of the speakers said to get the correct answer, then when they got an unknown words they focus to find the meaning that words. 
8) Problem pertinent to infer meaning

All of the listener have a problem to infer meaning in listening comprehension. Based on the questionnaire, there were 24 students have responded said that they difficult to infer meaning while listening. The students did not know how to infer meaning because they have no much knowledge about listening and they limited English vocabulary. The students have to know how to infer meaning because understanding spoken language is essentially an inferential process based on perception.

9) Problem pertinent unable to concentrate when answer and listen at the same time

There were only 13 students said yes and 24 said no. It means that a few student find difficulties to concentrate when answer and listen at the same time. It was because limited time of English Listening comprehension test. They did not have time to think what the correct answer. It shows that the students were not able to concentrate because they search the answer, at the same time, listen to the dialogue.

10) Problem pertinent to hear new words

There were 24 students have responded the students lose concentration when they hear new words in listening. They lose their concentration because they think too much to find a better answer. It shows that the students need good strategy so that they will be able keep concentration. They often tried to catch everything they heard, they felt panic when they failed to recognize a word or a structure.

11) Problems pertinent to recognize the word

There were 33 said yes and only 4 said no. Almost all students have responded that they unable to recognize the word because the way speaker pronounce. The word were pronounced differently from it was learn. At this point, the listener may not recognize it as the same words or may even miss its existence completely. The different culture may be influence this problem.

12) Problem pertinent to predict what would come next

There were 26 students answered yes and there were 11 answered no. It shows that the students find difficult to predict what would come next. The students who encountered this problem will interfere their listening.

13) Problem pertinent to memory

The students' respond shows that there were 24 students said yes and 13 said no. It means that the student find difficult to quickly remember about word that they have just heard. When they forget what they heard, they will spend too much time on translating and 


\section{Volume 3, Number 02, December 2017}

they cannot know which answer is correct. It shows that remembering of what just hear in listening very important thing.

14) Problem pertinent to question

There were 27 students said yes and 10 said No. it shows that the students found difficult to answer the question which required other than short answer. It because longer answers spend much time to translating and if there was many unfamiliar words. From this result, it is possible to infer many students find it difficult to answer which require longer answer.

15) Problem Pertinent Lack of Transcripts

The result shows that the majority of the students have responded they found difficult when listening English without transcript. From 37 students, there were 28 said yes and only 9 said no. The students answered yes, because they limited English vocabulary and limited knowledge about English. The lack of practice without transcript also make difficult to do it. It means that the transcript make them easy to check they have listened on the tape. Thus, they need to practice more and more listening without transcript because in listening test like TOEFL test need comprehend without transcript.

c. Listening Problem Related to Physical Setting

Not only the difficulties come from the message, listener, but also come from environment the students it called physical setting. Noise and poor quality CD player disturb students in listening comprehension.

1) Problem pertinent lose concentration because poor quality of recording

The result of the questionnaire shows that there were 29 students said Yes and 8 students said No. Many students have answered that poor quality of recording interfere their listening comprehension because they lose concentration. They cannot focus what the speaker said.

2) Problem pertinent of hesitation and pause

The result indicated that 32 students said yes and 5 students said No. It means that many students have responded that they found difficult to understand the listening text which is full hesitation and pauses. It was because hesitation and pause will make them difficult to interpret meaning what the speaker said.

3) Problem pertinent of lack visual support

There were 19 students said yes and 18 students said no. It shows that some students found difficult to understand spoken text without seeing the speaker's body language. When 
they see speaker body language, they will be easy to interpret the meaning of the speaker said. This deprives them of some contextual clues which make the message easily understood as they cannot see the speaker' face and gestures. Moreover, they have the added difficulty of remembering the setting and the individual speaker are not seen.

4) Problems pertinent to variety of accents

There were 32 students said yes and 5 students said no. It indicates that many students difficult to understand spoken text because variety accents of the speaker. The students felt confused with British English and American English because the pronunciation and intonation are quite different. It shows that the students had to learn not only English language but also variations of it.

5) Problem pertinent speed of delivery

Speaker speak too fast is factor that interfere the students' comprehension in listening. The table indicates that there were 33 students said yes and 4 students said no. Many students point out that when the speaker speak too fast, it is difficult for them to understand what is being said, even if the words are familiar for them. Native speaker speak too fast make the students sometimes hear all the words as a single unit. At this point, difficulty with speed delivery because unfamiliarity with listening to native speaker. The students need to practice their listening by listen native speaker.

6) Problem pertinent lack of pauses

Lack of pauses is also considered as source of listening problems. Result shows that there were 31 students said yes and 6 students said no. Many students found difficult to understand the listening text when the speaker does not pause long enough.

7) Problem pertinent inability to get repeated

According to the students' responses, the problem that interfere their listening comprehension was inability to get repeated. Nearly 30 of 37 students find difficult to understand the spoken text if they are unable to get repeated. When they get repeated their listening will make easy to complete idea in listening but the fact that the listener cannot make the speaker repeat what they have just said. In listening comprehension test there are only once to listen one question, decision to replay the recording not in the hands of listeners. Accordingly, the students need to practice more and more listening TOEFL test without replay the recording.

8) Problem pertinent noise around 


\section{Volume 3, Number 02, December 2017}

Noise around listening test is an obstacle to comprehension. The result indicated that there were 29 students said yes and 8 students said no. When noise in the room and the poor preparation of lab, will make the students cannot concentration on listening to the recording material. It is sure that noises around will not have good result in listening.

9) Problem pertinent poor quality tapes or disks

Another problem connected with listening was poor quality of the tapes. The data indicated that there were 22 students said yes and 15 students said No. Majority students have responded that the difficulties that they faced in listening comprehension because poor quality tapes or disks. Poor quality of tape will make sounds of the speaker is not clear and make us lose concentration.

10) Problem pertinent poor equipment

The result also shows that there were 27 students said yes and 10 said no. It means that not only poor-quality of the tapes disturbed listening comprehension but also unclear sounds resulting from poor quality equipment.

\section{The result of interview}

The interview was carried out with 7 volunteer students as discussed in research methodology. These interview due to know deeply about students' difficulties in listening comprehension. The questions from interview generally were taken from questionnaire. There are five question to know about students difficulties, the first question was: "What problems that affect your listening comprehension as the listener?", the second question was "What are the difficulties in listening material?", the third question was "What are the difficulties in listening material?", the fourth question was "What make you lose concentration during listening comprehension test?", the last question was "Have you ever used own personal experience or background knowledge to answer the question in listening? Why?" All of the questions in interview used English because the volunteer students from English education department but when they were asked to respond in English, they felt shy. So, they were allowed to use Indonesia.

a) Problems Affect Listening Comprehension

First question were asked to know the problems affect students listening comprehension as the listeners. The result showed all of the interviewee have various answer, almost all of them found difficult in listening comprehension because they poor knowledge of grammar and lack of vocabulary. The other problems are the length of content material, speaker spoke too fast, and unclear pronunciation. 
b) Problems toward Listening Material

The second questions were asked to know what make them difficult in content material of listening comprehension. The result of the second question showed, all of participants responded that the difficulties in content material are unfamiliar topic and long conversation of listening. There were only two students' said the difficulties in listening material are variety accents and grammar rules of the sentence.

c) Problems to Answer the Question during Listening

The third questions were asked to know the problems encountered by students to answer the question during listening. There were some problems the students cannot answer the question from the tapes. Among these, difficult to catch meaning because lack of vocabulary and poor grammar knowledge, they also lose concentration because focus to know unknown words. Consequently, they missed what the speaker said in the next question and so on, so they felt panic and make them difficult to answer the question.

d) Problems Lose Concentration during Listening

The fourth questions were asked to know what problems that make students lose concentration during listening comprehension. The students' answer showed that average of them said the problems make them lose concentration is noise in laboratory. The others problem is if the students cannot understand what the speaker said, this interrupts their heard. It means that failure concentrate will make them missing what the speaker said.

e) Problems Used Personal Experience

The fifth questions were asked to know the students use own personal experience to answer the question from the speaker. The students' respond indicated that all of them have used their personal understanding to complete the meaning what the speaker said and to answer the question. It means that prior knowledge is a powerful and very frequently used to catch the meaning of a listening comprehension task.

\section{E. CONCLUSION AND SUGGESTION}

\section{Conclusion}

All of students are unable to comprehend listening text. There are ten problems in students' self learning that were found in analyzing students' difficulties, they were : lack of vocabulary, poor grammar mastery, accent, pronunciation, lack of concentration, speed of speech, anxiety, noisy, inability to apply listening strategy, bad quality of recording. It is correct that the problems in listening comprehension faced by students' not only from the 


\section{Volume 3, Number 02, December 2017}

listeners themselves but also from content material and environment of listening comprehension. Hence, the students have to study hard and have more practice to improve their listening comprehension.

\section{Suggestion}

Based on the result study formerly, listening is one of difficult skill for students as foreign language learners even though they are students in English Education Department. Although students encountered various kinds of problems in listening comprehension, they need to study hard to become better listeners. Because listening is one of the important skills that it provides input for the learners not only in language learning but also in daily communication. Accordingly, the researcher offers the following suggestions:

a) The students as the listeners

The students need to train their listening at home intensively in order to help them overcome their problems about the topic in listening. They need to always listening also various accents by listening to the English songs or watching TV. It will help them to improve their vocabulary automatically. When the learning process, ask the lecturer about clarification the answer of the question and let the lecturer know if you don't understand something. Furthermore don't forget to apply listening strategies which become the main point if you want to success in listening comprehension test. Keep positive thinking of your listening comprehension test.

b) The lecturer of English

English lecturer should prepare their students to know the importance of communication skill and put a good strategy to teach them such as role play, it will train them to ask and answer. The lecturers also need to be aware about students' psychological. Both anxieties, boredom will interrupt in their learning and it indicates as a barrier in their listening comprehension test. The lecturer also should become more aware of the problems encountered by their students in academic to find a good strategy to teach in order to make the students become a better listener.

c) The reader

In order to get more a representative result, a replication study with a broader population is suggested and giving more attention in using instrument which are used for the students at university. It is also suggested that analyzing the result of the data have to finish after just know you have taken in order to make you fresh remember what you have done while research. Don't forget to take note and photo during research. 


\section{REFERENCES}

Abdullah, U., \& Rahman, I. F. (2017). The Correlation Between Students'habit In Watching Movie And Listening Skill. ETERNAL (English, Teaching, Learning, and Research Journal), 3(1), 97-106.

Abidin, Mohamad Japre Zainol. (2013). English Listening Comprehension Problems of Students from China Learning English in Malaysia, vol.13 April, 2013. http://www.languageinindia.com/april2013/chinastudentsenglishfinal.pdf. (Retrived on Mei $\left.24^{\text {th }}, 2016\right)$

Anadapong, Suradej.(2011) A study of English Listening Problems and Listening Proficiency of Bussines Students at Bangkok. Thammasat University, bangkok, 2011.

Anwar, T. Y., Naro, W., \& St Nurjannah, Y. T. (2017). Chart Filling As A Transfer Information Activity In Teaching Listening Comprehension at SMAN 1 Benteng, Selayar. ETERNAL (English, Teaching, Learning, and Research Journal), 3(1), 25-34.

Arikunto, Suharsimi. (2013) Prosedur Penelitian: Suatu Pendekatan Praktik. Jakarta: PT. Rineka Cipta.

Bingol, MA Mustafa Azmi.(2014). Listening Comprehension Difficulties Encountered By Students in Second Language Class. International Journal on New Trendsin Education and their Implications, vol.4, 2014. www.ijonte.org

Buck, G. (2001). Assessing Listening. Cambridge: Cambridge University Press, 2001 www. Cambridge .org

Burford, Lindsay. What problems do your learners have with listening.Language School, UABC: Tijuana México.

Cresswel, (2009). John W. Research Design : Qualitative, Quantitative, and Mixed Methods Approache, University Nebraska-Licoln : Sage Publication.

Damopoli,(2014) Muljono. Pedoman Penulisan Karya Tulis ilmiah. Makassar: Alauddin Press.

Dictionary. Camridge.org student in British English.

Doff, A and becket, C. (1991). Listening 1. Cambridge : Cambridge university press, Farlex. www.thefreedictionary.com.2012 


\section{Volume 3, Number 02, December 2017}

Field, John(2008). Listening in Language Classroom. Cambridge: Cambridge University press, 2008

Goh, C. (2000). A Cognitive Perspective on Language Learners' Listening Comprehension Problems.System, 28, No. 1.

Goh, C. (2010). Listening as Process: Learning Activities for self-appraisal and self regulation, in Nigel Harwood and Jack C.Richard ed, English language Teaching Materials. Amerika :Cambridge University Press.

Hamouda, A. (2003). An Investigation of listening Comprehension Problems Encountered by Saudi Students in the EL Listening Classroom. HR Mars: International Journal of Academic Research in Progressive and Development.

Harmer, Jeremy.(2007). How to Teach English. England : Longman Pearson Education.

Harmer, Jeremy. (2006). The Practice of English Language Teaching, $3^{\text {rd }}$ edition. Longman : Pearson Education Limited.

Harmer, Jeremy. (2006) The Practice of English Language Teaching, $4^{\text {th }}$ edition. Longman : Pearson Education Limited.

Helgesen, M and Steven Brown. (2007). Practical English languageTeaching Listening.David Nunan,ed.The McGraw-Hill Companies.

Hien, Trinh Vinh. Difficulties And Stategies In Listening Comprehension.Truong Dai Hoc Lac hong: Lac Hong university, 2015.http://lhu.edu.vn/139/662/DIFFICULTIES-ANDSTRATEGIES- IN -LISTENING COMPREHENSION-TRINH-VINH-HIEN03AV4.html. (Retrived on November $15^{\text {th }}, 2016$ )

Mukarrama, A., Mardianah, H., \& Said, A. M. (2015). Improving Students'listening Ability By Using Chain Whispering Words Or Sentences Technique At The First Year Of Smp Somba Opu Sungguminasa Gowa. ETERNAL (English, Teaching, Learning, and Research Journal), 1(2), 270-284.

Miles, M. B. \&Huberman, A. M.(1984). Qualitative Data Analysis: A Sourcebook of New Methods: California, 1984.

Meriam, Meriam Webster Dictionary, 1828. https://www.merriamwebster.com/dictionary/observation1828 (Retrived on November $15^{\text {th }}, 2016$ ) 
Oxford . 2008). Oxford Learner Pocket Dictionary, Oxford: Oxford University Press.

Saricoban, Arif. The Teaching of Listening. The internet TSEL Journal: Hacettepe University, 1999.http://itesli.org/(Retrived on November $\left.15^{\text {th }}, 2016\right)$

Nurpahmi, S. (2013). Difficulties Encountered By The Buginese Learners In Producing

English Sounds. Lentera Pendidikan: Jurnal Ilmu Tarbiyah Dan Keguruan, 16(1), 83-90.

Nurpahmi, S. (2015). Improving listening Skill By Activating Students'prior Knowledge. ETERNAL (English, Teaching, Learning, and Research Journal), 1(1), 28-38.

Nurpahmi, S. (2013). An Introduction to English for Specific Purposes. Makassar: Alauddin University Press.

Nurpahmi, S. (2014). English for Specific Purposes: An Integrated Approach. Makassar: Alauddin University Press.

Sugiyono. (2013). Cara Mudah Menyusun: Skripsi, Tesis, dan Disertasi. Alpabeta :Bandung.

Yagang, F (1994). .Listening: Problems And Solutions.In T.kral(ed)Teacher Development:Making The Right Moves Washington, DC: English language program divisions, USIA.

Yousif, Amna Abdelgadir.(2006) Listening Comprehension Difficulties as Perceived. Almajmah, Saudi Arabia. 